\title{
A study on awareness and adoption of smart technologies in libraries of engineering colleges in Karnataka
}

\author{
Manjunatha K ${ }^{1 *}$, Kumar Patil ${ }^{2}$ \\ ${ }^{1,2}$ Librarian, ${ }^{1}$ Govt. First Grade College, Kyathanahally, Mandya, Karnataka, ${ }^{2}$ Govt. First Grade College for Women, Byrapura, Mysore, \\ Karnataka, India
}

*Corresponding Author: Manjunatha K

Email: arkmanju@gmail.com

\begin{abstract}
Latest technologies have always caught the attention of library professionals as such technologies have been considered as potential platforms to offer improved library services. In addition, library professionals have also kept in mind that such technologies can offer a good number of flexible options for library users. Many such technologies such as Internet of Things (IoT), Electronic resource management (ERM), Data mining, Artificial intelligence (AI), Blockchain Technology and Augmented Reality etc. are beginning to make an entry into library space. Such ultra-modern, cutting edge technologies are grouped under the category 'smart technologies'. Libraries of engineering colleges have always had first exposure to latest technologies due to easy access. With this premise in mind, this research is done to investigate the extent of awareness about smart technologies among library professionals working engineering colleges of Karnataka and consequent adoption of such technologies by them. Survey method was used for data collection and collected data was analyzed using Statistical Package for Social Sciences (SPSS) for various parameters with findings that majority of the library professionals belonging to engineering colleges in Karnataka are already familiar with the term "smart libraries" and are using smart technologies for library purposes.
\end{abstract}

Keywords: Smart libraries, Smart technologies, Internet of things (IOT), RFID, Library services, Web based services.

\section{Introduction}

Libraries since their creation during the early civilizations till date have always worked towards goals of gathering, storing, preserving and retrieving information whenever needed. During these processes they have acquired and adopted prevailing methods and technologies to ease the processes. From the crude manual methods to the modern information and communication technologies libraries have always been the front runners in adoption of such methods and technologies. Automated technologies have been successfully implemented by libraries. A new generation of technologies under the name smart technologies which are more interconnected, more personal are evolving. When such smart technologies are adopted by the libraries, "Users will obviously gravitate towards smart libraries when they experience quality service resulting from technology adoption" (Yusuf, F., Owolabi, S., \& Ifijeh, G., 2019).

\section{What is a smart library?}

Gaohui, Mengli and Xuguang (2018) observed that some libraries adopted "smart" ways to solve the challenges of unprecedented data growth and technological change using new technologies to improve their services. They termed such libraries commonly as "smart libraries". But they also observed that due to lack of theoretical exploration it was difficult to define what a smart library is and how it differs from other libraries. With this backdrop, there is a need for identification of operational scope of smart libraries. The term "smart" refers mainly to efficiency due to the use of technologies and to an automatization of processes to facilitate the working and everyday environment (Freyberg, 2019). Keeping in view this operational definition it can be safely said that a "Smart Library" consists of all emerging technologies that can be suitably introduced to cater to the local requirements.

\section{Objectives of the Study}

The general objective of this study is to examine the use of smart technologies for library services by library professionals in engineering colleges of Karnataka.

The specific objectives include:

To study the awareness smart libraries in library professionals working in engineering colleges of Karnataka. To find out the level of adoption of smart technologies in library services by library professionals working in engineering colleges of Karnataka.

\section{Statement of Hypotheses}

1. Library professionals working in engineering colleges of Karnataka are aware of smart technologies

2. Library professionals working in engineering colleges of Karnataka have adopted smart technologies

3. There is no significant relationship between the age of the Library professionals, their gender, their academic status with awareness and adopting smart technologies in their library services.

\section{Survey of Literature}

Smart libraries revitalized with enriched content and digital space, modern library infrastructure and physical space could revolutionize access to information and knowledge and leap frog into the mainstream to cater to the skills and information needs of the 21st century. (Kulkarni, \& Dhanamjaya, 2017). These being the case there can be no doubt that traditional libraries are no longer relevant and they need to be reinvented. How this can be achieved is explained by Baryshev, Verkhovets, \& Babina (2018) who found that a 
traditional library can be transformed into a smart library by strategic design and implementation of advanced technologies, such as cloud computing, data mining and AI along with user cultivation and librarian training.

Further, Schöpfel (2018) developed an outline of a new concept of the smart library with four dimensions, i.e., smart services, smart people, smart place, and smart governance with observation that the smart library concept does not constitute a unique model or project but it is a process and a way of how to get things done, that is less linear, less structured, and more creative and innovative.

Further, librarians of this age have a need to adopt new roles and technologies to match user's expectations for new modes of communication and access to information (Vassilakaki \& Garoufallou, 2015). But Johnson (2012a) found that most librarians do not feel at home in using emerging modern technologies and prefer using traditional methods.

\section{Methodology}

This study adopted survey research method to examine the level awareness and adoption of smart technologies in library services in engineering colleges of Karnataka. The population of the study comprised 200 library professionals of 107 engineering colleges in Karnataka affiliated to Visvesvaraya Technological University (VTU) Belagavi. Stratified random sampling technique was used to obtain proportionate sample size from librarians of the engineering colleges located in Karnataka affiliated to VTU. Selfdesigned questionnaire was used as the research instrument for this study where 5type Likert scale was used to measure the respondents' level of awareness on smart technologies. 200 copies of the questionnaire were distributed among the sample population, out of which 180 were returned and 176 were found usable. Statistical Package for Social Sciences (SPSS) was used to analyze the collected data. Statistical methods used for the analyses of the data were frequency distribution, cross tabulation, T-test, and ANOVA test.

\section{Data Analysis and Results}

The demographic variables of the library professionals considered were: gender, age, designation, length of service and highest qualification along with their expressed opinions on the levels of awareness and adoption of smart technologies in library services.

Table1: Demographic Information of Respondents

\begin{tabular}{|l|c|c|}
\hline \multicolumn{1}{|c|}{ Variables } & Frequency & Percentage (\%) \\
\hline Gender & & 57.95 \\
\hline Male & 102 & 42.05 \\
\hline Female & 74 & 38.07 \\
\hline Age range & 67 & 41.48 \\
\hline 25-35 years & 73 & 15.34 \\
\hline 36-45 years & 27 & 05.11 \\
\hline 46-55 years & 09 & \\
\hline 56 years and above & & 03.41 \\
\hline Designation & 06 & 07.95 \\
\hline Chief Librarian & 14 & 32.95 \\
\hline Senior Librarian & 58 & 02.27 \\
\hline Librarian & 04 & 36.36 \\
\hline Deputy Librarian & 64 & 17.05 \\
\hline Assistant Librarian & 30 & \\
\hline Library Assistant & & 06.25 \\
\hline Length of Service & 11 & 35.80 \\
\hline Less than 5 years & 63 & 23.86 \\
\hline 6-10 years & 42 & 15.34 \\
\hline 11-15 years & 27 & 11.93 \\
\hline 16-20 years & 21 & 06.82 \\
\hline 21-25 years & 12 & $\mathbf{1 0 0 . 0 0}$ \\
\hline More than 25 years & $\mathbf{1 7 6}$ & \\
\hline Total & & \\
\hline
\end{tabular}

Out of 176 respondents, $102(57.95 \%)$ were male where as $74(42.05 \%)$ were females. This implied that, male library professionals were more in terms of number than the female. Out of 176 respondents who were between 25 and 35 age were 67(38.07\%), 36 to 45 years were $73(41.48 \%)$, while, $27(15.34 \%)$ of the respondents were between 46 and 55 years. Only 9 $(5.11 \%)$ of the respondents were above 56 years. The selection could therefore be said to include all ages of the library professionals. Out of the 176 respondent's majority of the respondents had their age range between 36 and 45 years which means that young male and female formed the bulk of the respondents. Also, majority $64(36.36 \%)$ of respondents were 
Assistant librarians, $58(32.95 \%)$ were librarians. Also, most 63(35.80\%) of respondents were good experience in their professional service.

Awareness and adoption of smart technologies

Table2: Awareness and adoption of smart technologies by respondents.

\begin{tabular}{|c|c|c|c|c|c|c|c|c|c|}
\hline \multirow{2}{*}{\multicolumn{2}{|c|}{ Variable }} & \multicolumn{3}{|c|}{$\begin{array}{l}\text { Awareness of smart } \\
\text { technologies in library } \\
\text { services }\end{array}$} & \multicolumn{3}{|c|}{$\begin{array}{l}\text { adoption of smart } \\
\text { technologies in } \\
\text { library services }\end{array}$} & \multirow[t]{2}{*}{$\begin{array}{l}\text { Statistical } \\
\text { inference }\end{array}$} & \multirow[t]{2}{*}{ Hypothesis } \\
\hline & & High & Moderate & Low & $\mathbf{F a}$ & $\mathbf{P a}$ & $\mathbf{N a}$ & & \\
\hline \multirow{2}{*}{ Gender } & Male & 72 & 26 & 4 & 39 & 59 & 4 & \multirow{2}{*}{$\begin{array}{c}x 2=12.965 \\
\mathrm{df}=5 \\
\mathrm{p}=0.0237\end{array}$} & \multirow[t]{2}{*}{ Rejected } \\
\hline & Female & 49 & 20 & 5 & 14 & 48 & 12 & & \\
\hline \multirow[t]{4}{*}{ Age Range } & $25-35$ years & 46 & 16 & 5 & 11 & 49 & 7 & \multirow{4}{*}{$\begin{array}{c}x 2=31.43 \\
\mathrm{df}=15 \\
\mathrm{p}=0.007690\end{array}$} & \multirow[t]{4}{*}{ Rejected } \\
\hline & $36-45$ years & 51 & 14 & 8 & 18 & 53 & 2 & & \\
\hline & $46-55$ years & 23 & 3 & 1 & 13 & 3 & 1 & & \\
\hline & $>56$ years & 7 & 1 & 1 & 1 & 2 & 6 & & \\
\hline \multirow[t]{6}{*}{ Designation } & Chief Librarian & 6 & 0 & 0 & 3 & 3 & 0 & \multirow{6}{*}{$\begin{array}{c}x 2=77.35 \\
\mathrm{df}=25 \\
\mathrm{p}=0.00015632\end{array}$} & \multirow[t]{6}{*}{ Rejected } \\
\hline & Sr. Librarian & 6 & 8 & 0 & 4 & 10 & 0 & & \\
\hline & Librarian & 49 & 8 & 1 & 21 & 35 & 2 & & \\
\hline & Dy. Librarian & 3 & 1 & 0 & 1 & 2 & 1 & & \\
\hline & Asst. Librarian & 43 & 18 & 3 & 19 & 43 & 2 & & \\
\hline & Library Asst. & 4 & 17 & 9 & 2 & 17 & 11 & & \\
\hline \multirow[t]{6}{*}{ Experience } & $<5$ years & 4 & 6 & 1 & 2 & 7 & 2 & \multirow{6}{*}{$\begin{array}{c}x 2=14.259 \\
\mathrm{df}=25 \\
\mathrm{p}=0.9570278\end{array}$} & \multirow{6}{*}{$\begin{array}{c}\text { Not } \\
\text { Rejected }\end{array}$} \\
\hline & 6-10 years & 47 & 13 & 3 & 19 & 40 & 4 & & \\
\hline & $11-15$ years & 30 & 10 & 2 & 9 & 28 & 3 & & \\
\hline & $16-20$ years & 18 & 7 & 2 & 7 & 15 & 5 & & \\
\hline & 21-25 years & 14 & 6 & 1 & 8 & 12 & 1 & & \\
\hline & $>25$ years & 8 & 3 & 1 & 3 & 8 & 1 & & \\
\hline
\end{tabular}

$* \mathrm{Fa}=$ Fully Adopted, $\mathrm{Pa}=$ Partially adopted, $\mathrm{Na}=$ Not adopted.

From the above Table 2 it has been inferred that majority of library professionals are much aware about concepts of Smart technologies which is suitable for effective library services, but they failed adopt smart technologies at full fledge due various reasons. It is clear from the above table that the significance value greater than 0.05 with variable namely gender, age and designation and hence null hypothesis is rejected. Interestingly association between awareness and adoption of smart technologies with academic experience is greater than 0.05 . Hence, we can say that there is significant difference between awareness and adoption of smart technologies with academic experience of respondents.

\section{Gender-wise awareness and adoption of smart technologies}

Respondents were asked about their awareness regarding familiarity with major smart technologies which were implemented in their libraries to facilitate the library users by them and also different library professionals from across the world.

Table 3: Gender-wise Awareness and adoption of smart technologies for library among respondents

\begin{tabular}{|l|l|c|c|c|c|}
\hline \multirow{2}{*}{$\begin{array}{l}\text { Awareness and adoption of Smart technologies } \\
\text { in library }\end{array}$} & \multicolumn{2}{|c|}{ Male } & \multicolumn{2}{c|}{ Female } \\
\cline { 3 - 6 } & Aware \& adopted & 97 & 95.10 & 69 & $\% 3.24$ \\
\hline \multirow{3}{*}{$\begin{array}{l}\text { Web based services } \\
\text { (eg., webopac, etc.) }\end{array}$} & Aware \& not adopted & 4 & 3.92 & 2 & 2.70 \\
\cline { 2 - 6 } & Not aware & 1 & 0.98 & 3 & 4.05 \\
\hline \multirow{2}{*}{$\begin{array}{l}\text { IOT based services } \\
\text { (eg., RFID technology) }\end{array}$} & Aware \& adopted & 1 & 0.98 & 3 & 4.05 \\
\cline { 2 - 6 } & Aware \& not adopted & 92 & 90.20 & 63 & 85.14 \\
\cline { 2 - 6 } & Not aware & 9 & 8.82 & 8 & 10.81 \\
\hline \multirow{2}{*}{$\begin{array}{l}\text { A I based services } \\
\text { ( eg, robot based services) }\end{array}$} & Aware \& adopted & 0 & 0.00 & 0 & 0.00 \\
\cline { 2 - 6 } & Aware \& not adopted & 91 & 89.22 & 54 & 72.97 \\
\cline { 2 - 6 } & Not aware & 11 & 10.78 & 20 & 27.03 \\
\hline
\end{tabular}




\begin{tabular}{|l|r|r|}
\hline Variance & 1996.25 & 832 \\
\hline Observations & 9 & 9 \\
\hline Pearson Correlation & 0.98555 & \\
\hline Hypothesized Mean Difference & 0 & \\
\hline df & 8 & \\
\hline t Stat & 1.64992 & \\
\hline P(T<=t) one-tail & 0.06878 & \\
\hline t Critical one-tail & 1.85955 & \\
\hline P(T<=t) two-tail & 0.13757 & \\
\hline t Critical two-tail & 2.306 & \\
\hline
\end{tabular}

Table 3 depicts gender-wise distribution of respondents on awareness and adopting smart technologies in libraries. The analysis shows that $97 \%$ of male respondents are aware and implemented the web based technologies like 'webopac' for library services against $95.10 \%$ of female library professionals. Similarly $90.20 \%$ male respondents are aware about IOT (Internet of Things) based technology like RFID technology but could not adopted for library services for various reasons in the library as against 85.14\% female respondents.89.22 \% male respondents and 72.97\% female respondents are aware about Artificial Intelligence (AI) based technologies like robotic technology in library services but they failed to implement in their libraries as they are highly expensive to adopt in libraries. $T$ independence test $(p>0.05)$ show that the awareness and implementing smart technology is significantly high among male than female library professionals.

Table 4: Age and Academic ranking-wise awareness and adoption of smart technologies for library among respondents.

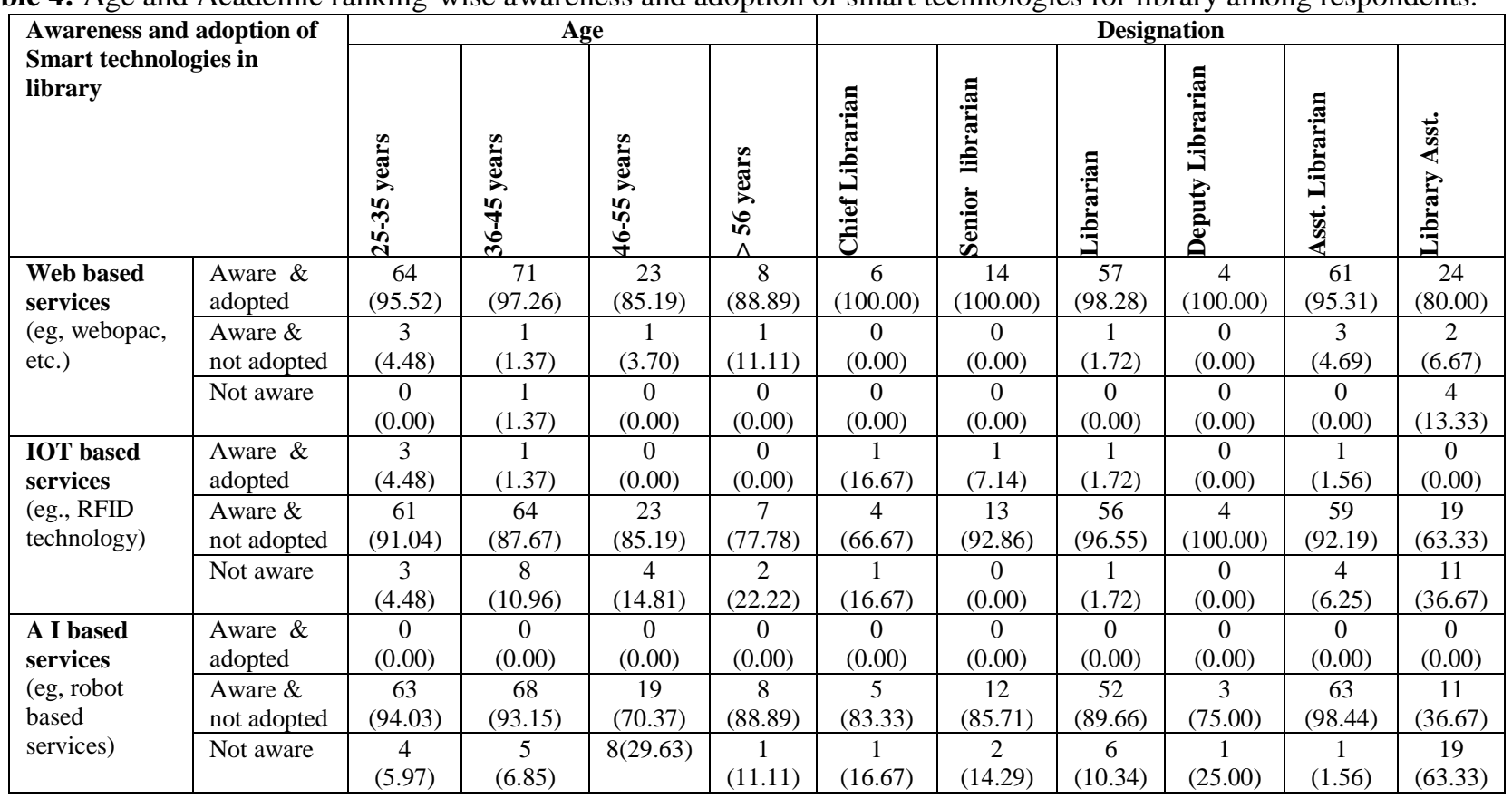

From the above table 4 it has been inferred that $100 \%$ of chief Librarian, senior librarians as well as Deputy Librarian are very much aware and as well as implemented and being utilize the web based services in their library services. Only $13.33 \%$ respondents of Library Assistant category are lagging behind in awareness about web based library services as library assistant professionals are not much exposures to innovative technologies available in the market.

\begin{tabular}{|c|c|c|c|c|c|c|c|}
\hline \multicolumn{8}{|c|}{ ANOVA ( Age of respondents) } \\
\hline Source of Variation & $S S$ & $d f$ & $M S$ & $F$ & $P$-value & F crit & Hypothesis \\
\hline Between Groups & 2918.75 & 3 & 972.917 & 1.85428 & 0.15725 & 2.90112 & \\
\hline Within Groups & 16790 & 32 & 524.688 & & & & Not rejected \\
\hline Total & 19708.8 & 35 & & & & & \\
\hline \multicolumn{8}{|c|}{ ANOVA (Academic Ranking) } \\
\hline Source of Variation & $S S$ & $d f$ & $M S$ & $F$ & $P$-value & F crit & Hypothesis \\
\hline Between Groups & 3445.33 & 5 & 689.067 & 2.37712 & 0.05256 & 2.40851 & \\
\hline
\end{tabular}




\begin{tabular}{|l|r|l|l|l|l|l|l|}
\hline Within Groups & 13914 & 48 & 289.875 & & & & Not rejected \\
\hline Total & 17359.3 & 53 & & & & & \\
\hline
\end{tabular}

The above table describes the comparison between factors affecting awareness and adoption of smart technologies with Age Factors. It is clear from the above table that the significance value greater than 0.05 , hence null hypothesis is not rejected. Hence, we can say that there is no significant difference between awareness and adoption of smart technologies with Age Factors respondents. Similarly comparison between factors affecting awareness and adoption of smart technologies against academic ranking viz, librarian, senior librarian, deputy librarian and library assistant. It is clear from the above table that the significance value greater than 0.05 , hence null hypothesis is not rejected. Hence, we can say that there is no significant difference between awareness and adoption of smart technologies with designation of respondents.

Table 5: The length of service wise Respondents' awareness and use of smart technology.

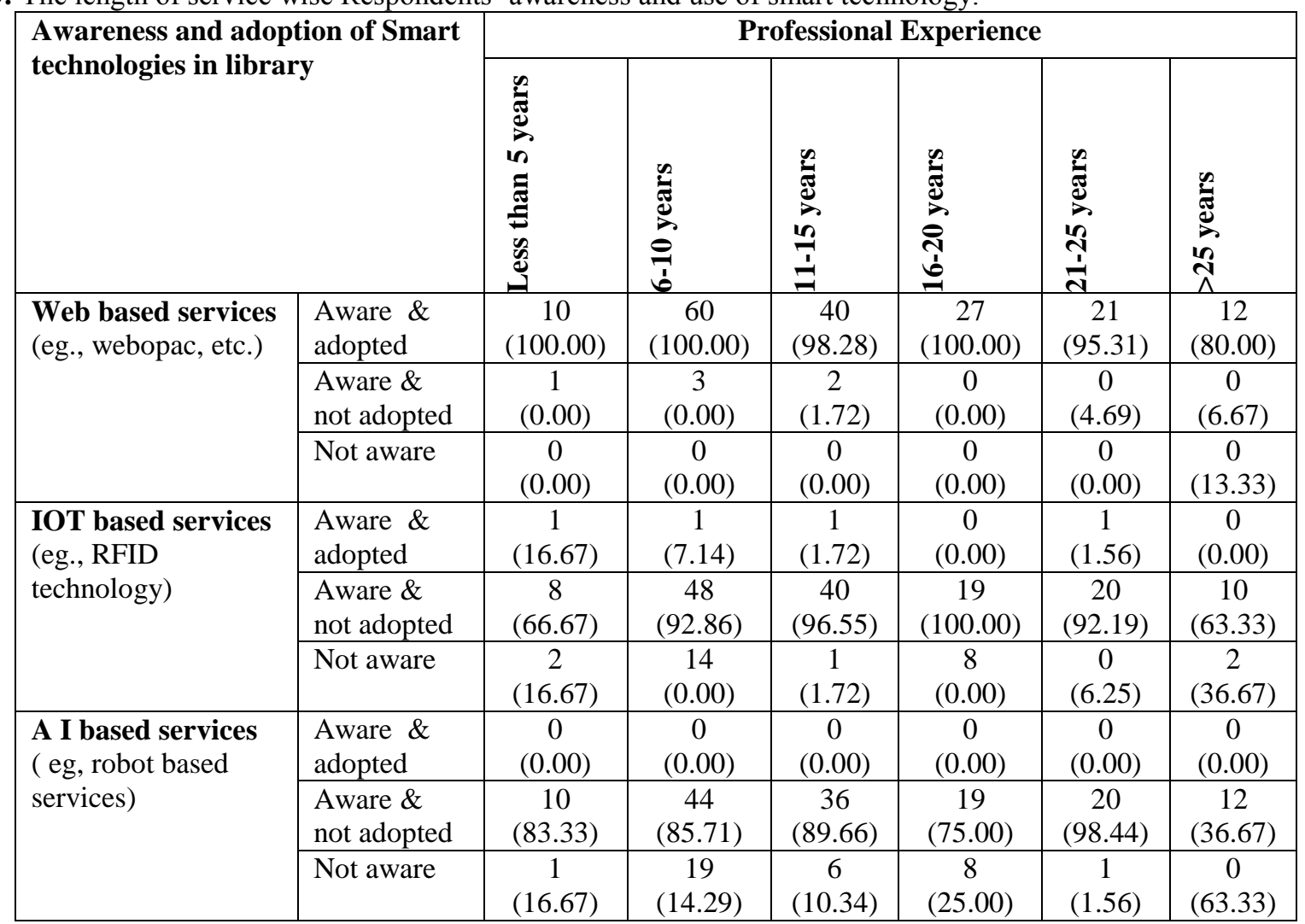

A keen observation of data in table 5 indicates that the length of service wise respondents awareness and adoption of smart technology in library services. It could be noted that respondents belong to less than 5 years' length of service $(100 \%)$ and respondents comes under the length of the service group in the range 6-10 years(100\%) are aware and adopting innovative technology like 'webopac' has been implemented rendering service to the academic community.

\begin{tabular}{|l|c|c|c|c|c|c|c|}
\hline ANOVA & & & & & & & \\
\hline Source of Variation & $S S$ & $d f$ & $M S$ & $F$ & P-value & F crit & Hypothesis \\
\hline Between Groups & 2187.33 & 5 & 437.467 & 2.30296 & 0.05914 & 2.40851 & \\
\hline Within Groups & 9118 & 48 & 189.958 & & & & Not rejected \\
\hline Total & 11305.3 & 53 & & & & & \\
\hline
\end{tabular}

The above table describes the comparison between factors affecting awareness and adoption of smart technologies with professional experience. It is clear from the above table that the significance value greater than 0.05 , hence null hypothesis is not rejected. Hence, we can say that there is no significant difference between awareness and adoption of smart technologies with length of experience of respondents.

\section{Conclusion}

There is no denial of the fact that engineering libraries are exposing themselves to modern technologies to offer better and improved services to their users. They are pioneers in putting technological innovations into practical applications. 
On the same lines, most of library professionals have acquired knowledge about concepts of Smart technologies which can be tweaked for offering better library services and are slowly putting them into practical use, but they have failed adopt smart technologies to a full extent due various reasons. This study reveals that libraries of engineering colleges in Karnataka are slowly bringing in smart technologies in libraries operational areas.

\section{Conflict of Interest}

None.

\section{Source of Funding}

None.

\section{References}

1. Baryshev R.A, Verkhovets S.V, Babina O.I. The smart library project. The Electronic Library, 2018;36(3):535-49. doi:10.1108/el-01-2017-0017

2. Freyberg, L. (2019, April 23). Smart Libraries. Retrieved June 25, 2020, from https://elephantinthelab.org/smart-libraries/

3. Gaohui Cao, Mengli Liang, Xuguang Li, (2018) "How to make the library smart? The conceptualization of the smart library",
The Electronic Library, https://doi.org/10.1108/EL-11-20170248

4. Johnson M.P. Connecting teacher librarians for technology integration leadership. School Libraries World Wide 2012;18(1):18-33.

5. Kulkarni, S., \& Dhanamjaya M, (2017.). Smart libraries for smart cities: A historic opportunity for quality public libraries in India. Retrieved June 25, 2020, from https://doi.org/10.1108/LHTN-08-2017-0061

6. Schöpfel J. Smart Libraries. Infrastructures, 2018;3(4):43. doi:10.3390/infrastructures3040043

7. Yusuf F, Owolabi S, Ifijeh G. Awareness of Internet of Things and its potential in enhancing academic library service delivery in a developing country. Library Philosophy and Practice (ejournal) pp. 2019;1-11. ISSN 1522-0222 (2831).

8. Vassilakaki, E., \& Garoufallou, E. The impact of Twitter on libraries: A critical review of the literature. Electronic Libr 2015;33(4):795-809. doi:10.1108/el-03-2014-0051

How to cite: Manjunatha K, Patil K. A study on awareness and adoption of smart technologies in libraries of engineering colleges in Karnataka. IP Indian J Libr Sci Inf Techno 2020;5(2):68-73. 